\title{
National hospice for the insane and the Brazilian Neurology in the beginning of the 20th century
}

Hospício nacional de alienados e a Neurologia brasileira no início do século 20

Marleide da Mota Gomes ${ }^{1}$, Maria Tavares Cavalcanti²

\begin{abstract}
The modern Brazilian Neurology was born in the campus of Praia Vermelha, Universidade Federal do Rio de Janeiro (UFRJ). The former National Hospice for the Insane (NHI) as well as some of its facilities were fundamental for the teaching about diseases of the nervous system to the students of the UFRJ's Medical School, caring for patients with neurosyphilis and epilepsy, as well as children with neurological impairment. We highlight the role of Juliano Moreira, director of the NHI (1903-1930), and his team, including Antonio Austregésilo Rodrigues Lima, the "father" of the Brazilian Neurology, in the construction of the modern Brazilian Psychiatry and Neurology.
\end{abstract}

Key words: Brazilian neurology, psychiatry, neuropsychiatry, history of neurosciences.

\section{RESUMO}

Os primórdios da neurologia moderna brasileira estão ligados ao campus da Praia Vermelha da Universidade Federal do Rio de Janeiro. 0 ex-Hospício Nacional de Alienados (HNA), bem como algumas de suas instalações foram fundamentais para o ensino sobre doenças do sistema nervoso aos alunos da Faculdade de Medicina do Rio de Janeiro; cuidado de pacientes com neurossífilis e epilepsia, e de crianças com comprometimento neurológico. Destacamos o papel de Juliano Moreira, diretor do HNA (1903-1930), e sua equipe, incluindo Antonio Austregésilo Rodrigues Lima, o "pai” da neurologia brasileira, na construção das modernas Psiquiatria e Neurologia brasileiras.

Palavras-Chave: neurologia brasileira, psiquiatria, neuropsiquiatria, história das neurociências.

The historiography of the modern Brazilian Neurology tracks back to the National Hospice for the Insane (NHI) at the beginning of the 20th century, when Juliano Moreira was its director ${ }^{1-3}$. The first patients referred to the hospital wards came from Santa Casa de Misericórdia do Rio de Janeiro (RJ), at the time of its foundation in 1852, named Hospice of Dom Pedro II then. With the establishment of the Republic, it was renamed to NHI.

\section{ASYLUM HEALTH MENTAL POLICY AT THAT TIME}

The NHI appointed director (1903), Moreira, had a training in biological Psychiatry ${ }^{2,3}$. He completed his course at the Medical School of Bahia with the work "Early malignant syphilis", and ran for the position of substitute professor at the section of Nervous Diseases in the same School with "Arsenic Dyskinesias"'. Moreira was dedicated to establishing the most scientific, modern and effective practice for the treatment of the mentally ill, mainly based on Emil Kraepelin ${ }^{4}$. A report by Afrânio Peixoto addressed in details the changes carried out at the NHI using ichnographic and administrative data ${ }^{5}$. He also pointed out the burden of illness at the NHI (Fig 1). Moreira was in consonance with the society repeated requests for the establishment of rehabilitation institutions for patients with alcohol problems, epilepsy, and intellectual disabilities in general ${ }^{5,6}$.

\section{PAVILIONS}

In 1893, the Observation Pavilion was created and has been ever since directed by a professor of Clinical Psychiatry and Nervous Diseases, from the Medical School of Rio de Janeiro, not by the director of the Hospice ${ }^{4}$. Antonio Austregésilo Rodrigues de Lima, the founder of the Brazilian Neurology, was appointed to the $\mathrm{NHI}$ in 1904 and became responsible for the male sector of the NHI (Fig 2). The routine care at the institution included an examination of the nervous system, where the patient would be submitted to percussion of the skull, as well as of the tendons, besides skin and pupil reflex assessment. Later on, anthropometric tests, which became more diversified and complex over time, were implemented 4 .

\footnotetext{
${ }^{1}$ Neurologist, Associate professor at Institute of Neurology, Medical School of Universidade Federal do Rio de Janeiro RJ, Brazil;

${ }^{2}$ Psychiatrist, Associate professor, director of the Institute of Psychiatry, Medical School of Universidade Federal do Rio de Janeiro RJ, Brazil.

Correspondence: Marleide da Mota Gomes; Programa de Epilepsia do Instituto de Neurologia Deolindo Couto; Universidade Federal do Rio de Janeiro (UFRJ); Avenida Venceslau Braz 95; 22290-140 Rio de Janeiro RJ - Brasil; E-mail:mmotagomes@acd.ufrj.br 


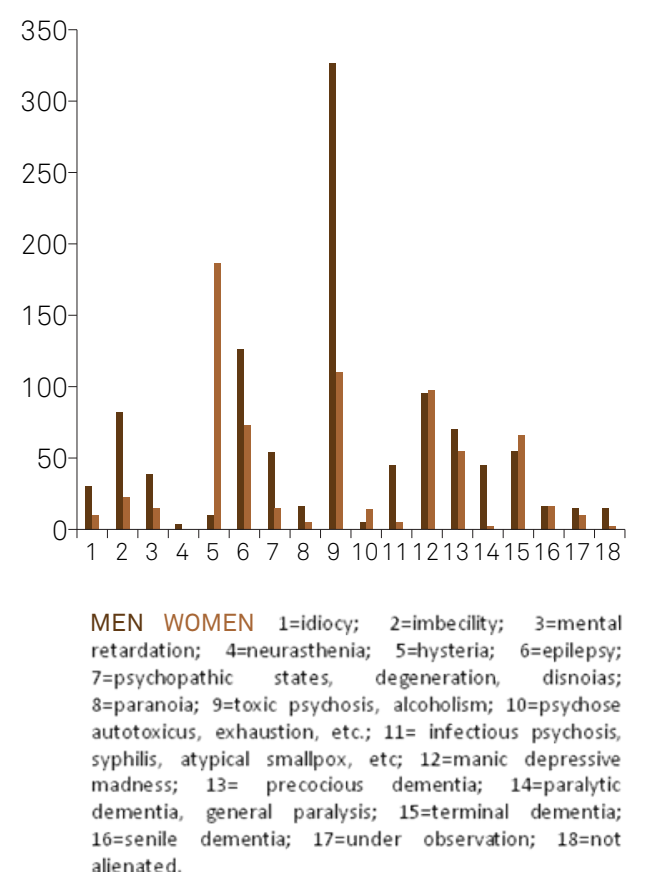

\begin{tabular}{|c|c|c|c|c|c|c|c|}
\hline Diseases & $M$ & $F$ & s & & $\mathrm{M}$ & $\mathrm{F}$ & s \\
\hline Pulmonary tuberculosis & 6 & 29 & 35 & Cerebral softening & 1 & 1 & 2 \\
\hline General paralysis & 2 & - & 2 & Meningitis & 2 & - & 2 \\
\hline Marasmus, cachexia & 0 & & & Meningoencephalitis & 1 & 1 & 2 \\
\hline (catatonic, lipemaniacos, etc.) & & 1 & 0 & Mitral regurgitation & 1 & - & 1 \\
\hline Enterocolitis & 4 & 6 & 20 & Arterio-venous aneurysm & 1 & $\cdot$ & 1 \\
\hline Cardiac syncope & 2 & 15 & 17 & Uncirinariose & 1 & $\cdot$ & 1 \\
\hline Dysentery & 3 & 12 & 15 & Angiocolite & 1 & - & 1 \\
\hline Pneuronia & 9 & 3 & 12 & Severe jaundice & 1 & $\cdot$ & 1 \\
\hline Arteriosclerosis & 3 & 4 & 7 & Gangrene of the rectum & 1 & - & 1 \\
\hline Acute delirium & 3 & 3 & 6 & Acute peritonitis & 1 & - & 1 \\
\hline Status epilepticus & 3 & 3 & 6 & Bromic coma & 1 & $\cdot$ & 1 \\
\hline Nephritis & 2 & 3 & 5 & Uremic poisoning & 1 & $\cdot$ & 1 \\
\hline Scurvy & - & 4 & 4 & Decubitus acute & 1 & $\cdot$ & 1 \\
\hline Beriberi & 2 & 2 & 4 & Erysipelas & 1 & $\cdot$ & 1 \\
\hline Myocarditis & 4 & - & 4 & Septicemia and suppurative otitis & 1 & $\cdot$ & 1 \\
\hline Nervous syphilis & 2 & 1 & 3 & Aortic narrowing & & & \\
\hline Brain hemorrhage & 3 & - & 3 & Cardiac stenosis & - & 1 & 1 \\
\hline Senile marasmus & 3 & - & 3 & Profoundanemia & - & 1 & 1 \\
\hline Asphyxia (suffocation and & 3 & - & 3 & Delirium tremens & $\cdot$ & 1 & 1 \\
\hline submersion) & 1 & 1 & 2 & Poliesteatose visceral & - & 1 & 1 \\
\hline Aortic insufficiency & 1 & 1 & 2 & & - & 1 & 1 \\
\hline Typhoid fever & 2 & - & 2 & & & & \\
\hline
\end{tabular}

\section{$\leftarrow$ Various types of madness}

Fig 1. National hospice for the insane inpatients. Left: causes for hospitalization (mainly alcoholism for men, and hysteria, for women. "Dementia precoce" and epilepsy are also relevant causes); Right: death causes (mainly tuberculosis, "general paralysis" and marasmus) (report of 1904-1905, by Afrânio Peixoto5).

To overcome the problems reported by previous commissions, new pavilions were built for children and epileptic patients. Those prepared for the epileptics "quiet" or "semiquiet" were: the Griesinger (for women) and Guislain (for men) ${ }^{7}$. Special beds were lined with wooden boards to prevent patients from falling in case of nocturnal seizures. Back then, it was believed that patients with epilepsy had symptoms that could lead them to commit the worst kind of folly, so they should go through a process of social rehabilitation and were kept from living freely in society ${ }^{6,8}$. Lima Barreto, famous writer and NHI patient, supported this idea when he described the behavior of a colleague. In his view, this patient had an "illusory sanity" because of his delusion from time to time ${ }^{8}$. The same writer, according to Neves ${ }^{9}$, looked at a boy with epilepsy and imagined his dark fate: "the whole damn life imprisoned by the attack, whose appearance cannot be predicted..." For treatment and reduction of seizures, according to Lemos ${ }^{7}$, the sectors were suggested a modification in diet, so it should become vegetarian, dechlorinated, and the patient should not take any kind of stimulating beverage such as coffee. Satisfactory results were only obtained in the female sector, according to Lemos?

The Bourneville Pavilion-School was founded in 1904, and directed for 15 years by Fernandes Figueira9 ${ }^{9}$. The institution held a room with exercise equipment, for education to boys and girls, with proper beds and garden sets. As recommended by Desire Magloire Bourneville, it was the first medico-pedagogical oriented institution in Brazil ${ }^{10}$. The

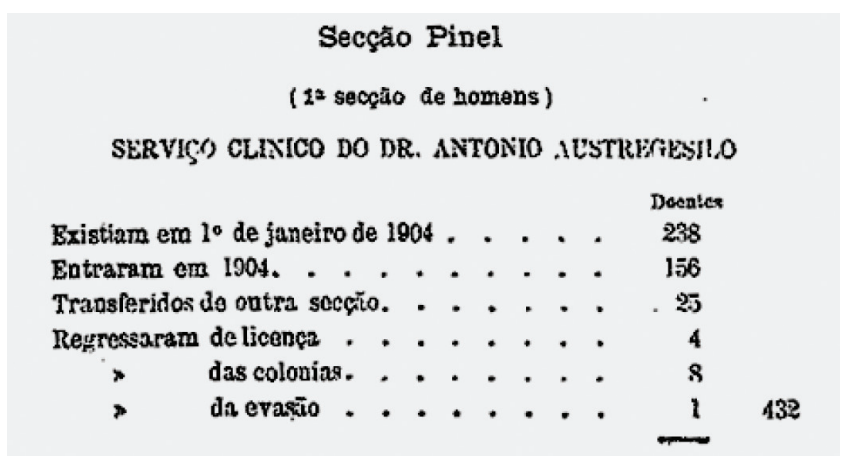

Fig 2. Antonio Austregésilo Rodrigues Lima: head of the Pinel Section of the NHI (report of Afrânio Peixoto5).

patients were divided into groups. Call attention to the clientele division on valid and invalid, to the purpose of education or simple rehabilitation and/or hygiene measures.

Moreira installed a clinical laboratory and established a routine for diagnostic lumbar puncture. The relevance of neurosyphilis in the first decades of the 20th century coupled with the great interest in the subject by Moreira influenced the later creation of the Institute of Neurosyphilis. Currently, it was turned into a psychiatric hospital named Philippe Pinel Institute.

In 1938, the former Observation Pavilion became the Institute for Psychopathology and Assistance Psychopaths (Fig 3), and transferred to the University of Brazil. Nowadays, it is known as Institute of Psychiatry of the Federal University of Rio de Janeiro (UFRJ). 


\section{SOCIETY AND JOURNAL AT THE NHI}

Moreira published several works in Psychiatry and severe systemic disease with potential coetaneous and neuropsychiatric repercussions (syphilis, leprosy and arsenic poisoning). Together with Afrânio Peixoto, he was the founder of the first national journal specialized in Neuropsychiatry, printed in the typography of the NHA: Arquivos Brasileiros de Psiquiatria, Neurologia e Ciências Afins (1905). It had, later on, its named changed to Arquivos Brasileiros de Psiquiatria, Neurologia e Medicina Legal (1908) because of a Society founded the year before which had the same name ${ }^{4}$. In 1919, the journal was named Arquivos Brasileiros de Neuriatria e Psiquiatria. From 1915, each field of knowledge had a responsible editor. Neurology was under the supervision of Austregésilo, with the collaboration of Faustino Esposel, Moreira da Fonseca and Waldemar Schiller.

\section{PRAIA VERMELHA CAMPUS OF UNIVERSIDADE FEDERAL DO RIO DE JANEIRO}

In 1944, the transference of the remaining patients of NHI was concluded. Afterwards, the area was handed over to Universidade do Brasil, currently known as UFRJ, where one of the institution's campi is located. From the former NHA medical services, the current Institute of Psychiatry, the Philippe Pinel Institute (next to the campus) and the Institute of Neurology (Fig 4) are still held. This latter was started with some modules for Austregésilo, in 1926. Deolindo Couto, Austregésilo's successor, established officially it in December $16,1946^{2}$.

\section{CONCLUSIONS}

The former NHI and surrounding areas was the birthplace of the modern Brazilian Neurology (besides the Psychiatry),

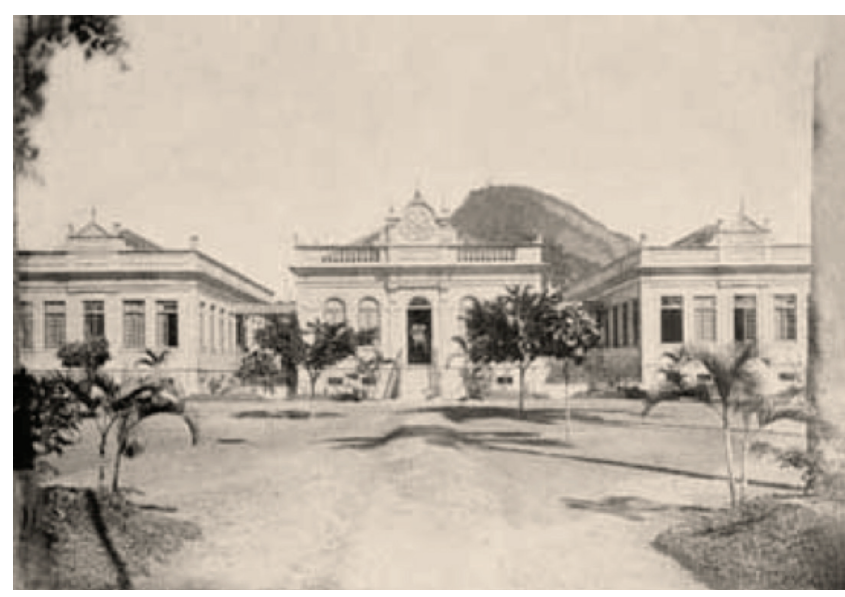

Source: http://www.ccs.saude.gov.br/memoria\%20da\%20loucura/mostra/ hpii.html and Library Institute of Psychiatry.

Fig 3. Pavilion Observations - Current Psychiatry Institute, Universidade Federal do Rio de Janeiro.

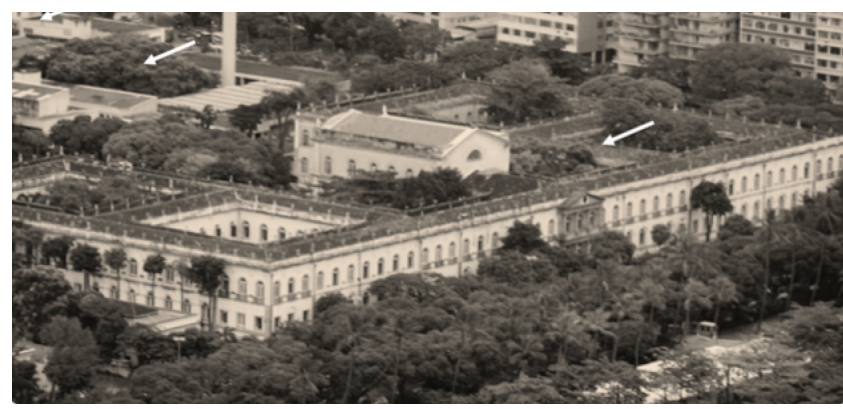

Source:http://upload.wikimedia.org/wikipedia/commons/8/8c/UFRJ-Praia_ Vermelha.jpg

Fig 4. Ancient National Hospice for the Insane founded in 1852 under the name of Dom Pedro II Hospice (nowadays, Forum of Science and Culture of the Universidade Federal do Rio de Janeiro): $1^{\text {st }}$ right arrow, Forum; $2^{\text {nd }}$, Institute Philippe Pinel, in the place of the Pavilion of Neurosyphilis of NHI; 3rd, Institute of Neurology.

primarily under the impulse of Juliano Moreira, in association with Afrânio Peixoto, but achieving great prestige and reputation at the time of of Austregesilo and Deolindo Couto.

\section{References}

1. Leme Lopes J. Juliano Moreira. J Bras Psiquiat 1964;13:3-19.

2. Gomes MM. O Instituto de Neurologia Deolindo Couto da UFRJ: suas raízes e desdobramentos: uma visão histórica e holística. Rev Bras Neurol 1996;32:193-202.

3. Gomes MM, Engelhardt E. Meynert and the Biological German Psychiatry. Arquivos de Neuro-Psiquiatria, In press.

4. Facchinetti C.No labirinto das fontes do Hospício Nacional de Alienados. Hist Cienc Saude-Manguinhos 2010;17(Suppl 2):S733-S768.

5. Peixoto A. Relatório apresentado ao Exmo. Sr. Dr. J. J. Seabra, Ministro da Justiça e Negócios Interiores, pelo Dr. Afrânio Peixoto, diretor interino do Hospício Nacional de Alienados (1904-1905). 73 p. In Brasil. Ministério da Justiça. Relatório dos anos de 1904 e 1905 , apresentado ao presidente da República dos Estados Unidos do Brasil pelo Dr.J.J. Seabra, em março de 1905. Volume II, Diretoria do Interior, segunda parte, anexo E. Rio de Janeiro: Imprensa Nacional,
1905. [cited 2012 Apr 24]. Available from: http://brazil.crl.edu/bsd/ bsd/u1889/000761.html

6. Moreira J. Assistência aos epilépticos: colônias para eles. Arq Bras Psiquiatr Neurol Ciências Afins 1905;167-182.

7. Lemos J. A propósito do tratamento dos doentes epilépticos no Hospital Nacional dos Alienados durante os anos de 1912 e 1913. Arq Bras Psiquiatr Neurol Med Legal 1915;5-30.

8. Arantes MA. Hospício de doutores. Hist Cienc SaudeManguinhos 2008;15:49-63.

9. Neves MS. O grande mal no Cemitério dos Vivos: diagnósticos de epilepsia no Hospital Nacional de Alienados. Hist Cienc SaudeManguinhos 2010;17(Suppl 2):S293-S311.

10. Silva RP. Medicina, educação e psiquiatria para a infância: o PavilhãoEscola Bourneville no início do século XX. Rev Latinoam Psicopat Fund 2009;12:195-208. 